\title{
Hubert Bąk
}

Uniwersytet Mikołaja Kopernika, Toruń

\section{Relacje między organami władzy ustawodawczej, wykonawczej i sądowniczej w świetle Konstytucji Królestwa Norwegii $\mathrm{z}$ dnia 17 maja 1814 roku}

DOI: http://dx.doi.org/10.12775/SIT.2014.002

\section{Rys historyczny}

Przełom wieku XVIII i XIX to czas wielkich zmian w ustrojach państw europejskich, okres ten można uznać za początek nowoczesnego konstytucjonalizmu i zmierzch konstytucjonalizmu feudalnego $^{1}$. Rozróżnienie powyższe jest ważne ze względu na spór panujący w piśmiennictwie prawno-historycznym, dotyczący możności uznania pewnych przywilejów średniowiecznych, jak np. angielska Wielka Karta Swobód z 1215 roku, za konstytucje stanowe. Konstytucjonalizm, w rozumieniu nowoczesnym, jest tematem wielu prac naukowych z pogranicza nauk prawnych i historycznych. Pojawienie się ustawy zasadniczej stanowi pewien przełom w historii ludzkości, wiąże się to $z$ odejściem od absolutyzmu i narodzinami władzy przedstawicielskiej opartej na monteskiuszowskim modelu funkcjonowania państwa. Szczególnie dużym zainteresowaniem

${ }^{1}$ Zob. M. Klementowski, Powszechna historia ustroju, Warszawa 2012, s. 327 i n. 
cieszą się pierwsze konstytucje, które traktowane są jako wzorcowe dla przyszłych m.in.: konstytucja Stanów Zjednoczonych czy konstytucja roku 1791 (Francja). Ze względu na Konstytucję 3 maja także w Polsce tematyka ta jest przedmiotem wielu rozpraw naukowych. Pomimo to na płaszczyźnie prawno-historycznej wciąż brakuje artykułów oraz monografii dotyczących jednej z najbardziej demokratycznych i liberalnych ustaw zasadniczych XIX wieku Konstytucji Królestwa Norwegii z dnia 17 maja 1814 roku.

Objętość materii konstytucyjnej oraz charakter pracy nie pozwalają na całościowe przedstawienie zagadnień unormowanych w konstytucji eidsvollskiej ${ }^{2}$. Celem moim jest więc zapoznanie odbiorcy jedynie $z$ wybranymi fragmentami norweskiej ustawy zasadniczej, które pod względem tematycznym stanowią logiczną całość, a dotyczą modelu organizacji funkcjonowania państwa, który oparty jest o monteskiuszowski model trójpodziału władzy. Integralnym elementem pracy jest także przedstawienie tła historycznego, które pomoże czytelnikowi zrozumieć, jak wielkim osiągnięciem było uchwalenie konstytucji eidsvollskiej, i w jak wielkim stopniu przyczyniło się to do poprawy pozycji Norwegii w sporze o jej niepodległość, który Norwegowie toczyli ze Szwecją na początku XIX wieku.

Historię Norwegii można podzielić na kilka okresów, które związane są $z$ różnymi fazami rozwoju państwa oraz jego prawodawstwa. Początek pierwszego okresu, przyjmując ustalenia norweskich historyków, wyznacza rok 872, kiedy to król Harald Pięknowłosy pokonał w bitwie pod Harsfjord swoich przeciwników i dokonał zjednoczenia ziem południowej Norwegii. Za końcową cezurę uznać można rok 1319 - powstanie szwedzko-norweskiej unii personalnej. Okres ten obfituje w wydarzenia, które doprowadziły do powstania państwowości norweskiej oraz umocnienia państwa. Przede wszystkim doszło do ukształtowania się systemu sądowego - oprócz króla ważną rolę odgrywały wiece dzielnicowe - tingi, zajmujące się

${ }^{2}$ Konstytucja Królestwa Norwegii z 17 maja 1814 roku jest potocznie nazywana konstytucją eidsvollską. Nazwa ta wzięła się od miasta, w którym została uchwalona. 
uchwalaniem nowych praw i wydawaniem wyroków ${ }^{3}$. Uprawnienia te przysługiwały także obecnemu na tingu królowi, przez co posiadał on bezpośrednią władzę sądową . Duże znaczenie dla konsolidacji kraju miało przyjęcie chrześcijaństwa przez Olafa I Tryggvasona w 995 roku. Dzięki temu posunięciu królowie norwescy zostali zaliczeni w poczet chrześcijańskich władców Europy - pierwsza kościelna koronacja miała miejsce w 1163 roku w Bergen, a pierwszym w ten sposób namaszczonym władcą został król Magnus V. W XIII wieku doszło także do ujednolicenia zasad dziedziczenia tronu: obowiązywała zasada primogenitury, dziedziczenia przez potomka $z$ legalnego związku małżeńskiego oraz możliwość objęcia tronu przez córkę królewską lub jej syna ${ }^{5}$. Za panowania króla Magnusa VI dokonano uzupełnienia, uporządkowania i ujednolicenia obowiązującego w Norwegii prawa, czego przejawem było wydanie Landsloven (prawa krajowego), Byloven (jednolitego prawa miejskiego), Hirdskrå (przepisów organizacyjnych drużyny królewskiej) oraz Jonsbok (ujednoliconego prawa Islandii z prawami Norwegii). W 1319 roku doszło do unii personalnej pomiędzy Szwecją a Norwegią. Począwszy od tego momentu, aż do roku 1814, Norwegia pozostawała w unii z którymś z państwa skandynawskich (1319-1364 - unia ze Szwecją, 1380-1814 - unia z Danią), będąc w tych związkach partnerem słabszym.

Za początek kolejnego okresu (celowo pomijam lata unii ze Szwecją, ze względu na małe znaczenie, jakie miała ona w historii kraju) przyjmuje się rok 1380, kiedy to wnuk duńskiego króla Waldemara IV - Olaf, został koronowany na króla Norwegii, co dało początek unii personalnej pomiędzy oboma królestwami. Cezurę końcową wyznacza zaś wprowadzenie absolutyzmu w 1660 roku. W roku 1397 doszło do zawarcia pomiędzy państwami skandynawskimi tzw. unii kalmarskiej. Spoiwem łączącym Szwecję, Norwegię i Danię

${ }^{3}$ A. Gaca, Kodeks duński króla Chrystiana V z roku 1683, Toruń 1992, S. 1.

${ }^{4}$ E. Gunnes, Norges historie bd. 2: Rikssamling og kristning 800-1177, red. K. Mykland, Oslo 1976, s. 94.

5 Zob. T.H. Aschehoug, Norges offentlige ret, bd. 1: Statsforfatningen i Norge og Danmark indtil 1814, Christiania 1866, s. 19-25. 
miała być osoba króla, polityka zagraniczna oraz wojsko. Każde z państw zachowywało swoje własne prawa. Związek ten okazał się bytem nietrwałym, co spowodowane było wewnętrzną rywalizacją o dominację, która toczyła się pomiędzy Duńczykami a Szwedami ${ }^{6}$. XIV wiek był wyjątkowo trudnym czasem dla Norwegii, która jako najsłabiej rozwinięte pod względem gospodarczym państwo unii, nie miała większego wpływu na wydarzenia w obrębie basenu Morza Bałtyckiego. Pozycja kraju uległa dodatkowo osłabieniu wskutek ograniczenia rozwoju najsilniejszej gałęzi norweskiej gospodarki handlu morskiego, który został opanowany przez miasta Hanzy. Dodatkowo w połowie XIV wieku przez kraj przetoczyła się epidemia dżumy, doprowadzając do zdziesiątkowania populacji kraju. Nadzieją na polepszenie sytuacji była koronacja pierwszego $z$ dynastii Oldenburgów na tronie duńsko-norweskim - króla Chrystiana I. W 1449 roku, w dokumencie zwanym håndfæestning ${ }^{7}$, król zobowiązał się uroczyście do rządów zgodnie $z$ prawem norweskim oraz nadawania urzędów państwowych Norwegom ${ }^{8}$. Monarchia miała być elekcyjna, a wyboru dokonywać miały wspólnie rady (rigsråd) obu państw, w skład których wchodzili przedstawiciele najważniejszych rodów oraz dostojnicy kościelni. Dodatkowo gwarancją niezależności w unii z Danią miał być podpisany w 1450 roku traktat bergeński, zgodnie z którym oba królestwa miała łączyć jedynie osoba króla, a stosunek pomiędzy nimi miał opierać się na „braterskiej miłości” (brødherlig kerlighet) i pomocy w razie wojny, a dla zagwarantowania równorzędności zachowano osobne prawa, rady państwa oraz przywileje $^{9}$. W rzeczywistości sytuacja nie uległa zmianie, Norwegią rządziła duńska rada państwa $z$ siedzibą w Kopenhadze, która po-

${ }^{6}$ Za kres unii uważa się rok 1523, kiedy szwedzkie zgromadzenie stanowe wybrało na nowego króla Gustawa Wazę, jednocześnie detronizując króla Chrystiana II.

7 Rodzaj pisemnej obietnicy do rządów zgodnych $z$ prawem oraz gwarancja innych zobowiązań, które były niejako warunkiem wyboru na króla; zob. P.J. Jørgensen, Dansk retshistorie, København 1969, s. 64.

8 T.H. Aschehoug, op.cit., s. 180.

9 Norges gamle lov, række 2: 1388-1604, bd. 2: 1448-1482, red. O.A. Johnsen, O. Kolsrud, A. Taranger, Oslo 1934, s. 55-56. 
dejmowała istotne dla obu państw decyzje $z$ zakresu polityki zagranicznej, prawodawstwa, wymiaru sprawiedliwości czy podatków ${ }^{10}$. W 1536 roku król Chrystian III ogłosił oficjalnie religię luterańską jako religię państwową - spowodowało to wzmocnienie pozycji monarchy przez przejęcie majątków kościelnych. W tym samym roku król podpisał håndfæestning, zgodnie $\mathrm{z}$ którym Norwegia została sprowadzona do roli duńskiej prowincji: „liksom ett av de andre landsdeler, Jylland, Fyn, Sjælland eller Skåne"11. Zlikwidowano norweską radę państwa, instytucje kościelne, a norweskie zgromadzenie stanów miało jedynie możliwość złożenia hołdu nowemu królowi bez wpływu na jego wybór. W 1572 roku wprowadzono urząd stattholdera - namiestnika kraju, który z ramienia Kopenhagi odpowiadał za sprawy administracyjne, kościelne oraz sądownicze. W 1660 roku, w wyniku rosnącego niezadowolenia rządami arystokracji - pod naciskiem duchowieństwa i mieszczaństwa, doszło do złożenia przez przedstawicieli stanów hołdu Fryderykowi III jako władcy dziedzicznemu ${ }^{12}$. Wydarzenie to zapoczątkowało okres absolutyzmu w Norwegii i Danii. W 1661 roku wydano dla Norwegii specjalny akt - enevoldsarveregjeringsakten, w którym oficjalnie uregulowane zostały kwestie związane $z$ pozycją króla: wprowadzono rządy absolutne monarchy oraz dziedziczność tronu ${ }^{13}$. Monarcha stał się prawodawcą, sędzią, nakładał podatki, mianował urzędników oraz podejmował decyzje w sprawach wojennych. W 1665 roku opracowane zostały nowe prawa - Kongeloven. Lex regia potwierdzało wszystkie nadane królowi uprawnienia i oficjalnie wprowadzało monarchię absolutną. Król przyrzekł, że nie wyrzeknie się wiary luterańskiej, nie podzieli swojej władzy oraz nie zrzeknie się żadnej $\mathrm{z}$ części królestwa ${ }^{14}$.

Ostatni okres poprzedzający uchwalenie konstytucji przez Zgromadzenie Narodowe w Eidsvoll, to lata 1660-1814 - czas od wpro-

${ }^{10}$ A. Bereza-Jarociński, Zarys dziejów Norwegii, Warszawa 1991, s. 61.

11 Norsk tro og tanke, red. J.E. Ebbestad Hansen, bd. 1, Oslo 1998, s. 176.

${ }^{12}$ K. Larsen, A history of Norway, New York 1950, s. 288.

13 S. Sogner, Aschehougs Norges historie bd. 6: Krieg og fred 1660-1780, red. K. Helle, Oslo 2005, s. 14-21.

${ }^{14}$ B.J. Nordstrom, Scandinavia since 1500, Minneapolis 2000, s. 57. 
wadzenia absolutyzmu do powstania norweskiej ustawy zasadniczej. Lata te wiążą się $z$ szeregiem działań zmierzających do utworzenia jednolitego państwa ze stolicą w Kopenhadze. W 1667 roku ukazała się kodyfikacja norweskiego prawa - Norges lov, która miała na celu doprowadzenie do zgodności prawa krajowego $z$ prawem duńskim. Okres ten związany jest także $z$ napływem duńskich urzędników, którzy zajmowali w Norwegii stanowiska w administracji państwowej. Kraj podnosił się z zapaści gospodarczej, rozwijały się handel oraz żegluga, czemu sprzyjały lata pokoju (od końca wojny północnej 1721 do roku 1807 monarchia Oldenburgów pozostawała poza areną działań wojennych). Pod względem gospodarczym Norwegowie zaczęli przewyższać swoich „sąsiadów $z$ Kopenhagi ${ }^{15}$. Sytuacja Norwegii uległa zmianie w roku 1807, kiedy to flota brytyjska, w toku działań związanych $z$ epoką napoleońską, zbombardowała Kopenhagę, co zmusiło niejako Oldenburgów do opowiedzenia się po stronie Francji. Sojusz ten wraz z upadkiem Napoleona doprowadził do porażki Oldenburgów. Duńczycy 14 stycznia 1814 roku zostali zmuszeni do zrzeczenia się na rzecz Szwecji swoich praw do Norwegii, co zostało przypieczętowane tzw. traktatem kilońskim. Działania te zostały uznane przez stattholdera Norwegii - księcia Chrystiana Fryderyka (będącego jednocześnie następcą tronu) za niezgodne $\mathrm{z}$ zapisem Kongeloven z 1665 roku, zgodnie $z$ którym monarcha nie miał uprawnień do zrzeczenia się jakiejkolwiek z części królestwa. Książę, przy poparciu norweskiego społeczeństwa, zwołał Zgromadzenie Narodowe, którego zadaniem miało być uchwalenie konstytucji. Po wydaniu przez księcia szeregu dokumentów dotyczących organizacji wyborów, 10 kwietnia 1814 roku Zgromadzenie rozpoczęło swoje obrady, które zakończyły się 17 maj. Owocem prac była Konstytucja Królestwa Norwegii będąca gwarantem niepodległości oraz odpowiedzią na szwedzkie roszczenia względem norweskich ziem.

15 Zob. L. Holberg, Dannemarks og Norges Beskrivelse, Kjøbenhavn 1729, s. 587-588. 


\section{Trójpodział władzy w Konstytucji Królestwa Norwegii z dnia 17 maja 1814 roku}

Norweska ustawa zasadnicza obowiązuje ze zmianami do dnia dzisiejszego. Patrząc przez pryzmat XIX wieku, można uznać ją za jedną z najbardziej nowoczesnych konstytucji czasów nowożytnych. Na jej treść wpływ miały m.in.: konstytucja francuska z 1791 roku, konstytucja szwedzka z 1809 roku, konstytucja Niderlandów z 1798 roku oraz konstytucja amerykańska $(1787)^{16}$. Reprezentanci społeczeństwa norweskiego, zasiadający w Zgromadzeniu Narodowym, w trakcie prac nad ostateczną treścią ustawy posiłkowali się także ideami oświeceniowymi, które uwidaczniały się w trzech podstawowych zasadach: suwerenności narodu, trójpodziału władzy oraz respektowania przez państwo podstawowych praw człowieka. Zasada samostanowienia została zaczerpnięta $z$ pracy Jeana Jacquesa Rousseaua - Umowa społeczna, gdzie lud miał być suwerenem odpowiedzialnym za stanowienie praw, a władza jedynie ich realizatorem. Wola ludu miała wyrażać się w prawach, a Storting (parlament) wybierany przez norweskich obywateli był wykonawcą tej woli i reprezentantem narodu. Drugi filar, czyli trójpodział władzy, został zaadoptowany z pracy Monteskiusza - O duchu praw. Konstytucja eidsvollska za francuskim filozofem zakłada rozróżnienie na władzę wykonawczą, ustawodawczą i sądowniczą. Zabieg ten miał wykluczyć nadużycia władzy przez organy skupiające w swoim ręku nadmiar kompetencji. Ideę trójpodziału oparto na trzech podstawowych zasadach: społecznym podziale władzy, funkcjonalno-organizacyjnym podziale władzy, a także wzajemnym hamowaniu władz (zasada checks ballances rozwinięta przez Aleksandra Hamiltona). W przypadku Norwegii władza ustawodawcza należała do Stortingu (w pewnym stopniu również do Króla, o czym w dalszej części tekstu), władza wykonawcza do Rządu oraz Króla, zaś władza sądownicza do sądów, na czele których stał Sąd Najwyższy ${ }^{17}$.

${ }^{16}$ Grunnloven med forklaringer, red. H. Hartmann, Oslo 1959, s. 3.

17 Ibidem, s. 4-5. 
Ostatnia zasada związana była $z$ podstawowymi założeniami myśli politycznej Johna Locke’a. Państwo musiało respektować elementarne prawa: do życia, posiadania, zrzeszania się czy wolności wypowiedzi. W norweskiej ustawie zasadniczej idee te wyrażały się w wolności słowa i druku, zasadzie lex retro non agit, czy w nakazie odszkodowania za bezprawne wywłaszczenie.

\subsection{Władza wykonawcza}

Zgodnie z $§ 1$ konstytucji „Królestwo Norwegii jest wolnym, niezbywalnym i niepodzielnym Królestwem. Jego formą rządów jest ograniczona i dziedziczna monarchia"18. Przepis ten był ukłonem w stronę przeszłości oraz myśli oświeceniowej. Norwegia pozostawała monarchią, a w nawiązaniu do tradycji korony norweskiej tron miał być dziedziczny ${ }^{19}$. Wraz z uchwaleniem konstytucji nastał kres władzy absolutnej - od 1814 roku Norwegia była monarchią konstytucyjną. Władza zwierzchnia została przekazana w ręce Narodu, którego reprezentantem był jednoizbowy parlament - Storting (,folket udøver den lovgivende Magt ved Storthinget, der bestaaer af 2 Afdelinger, et Lagthing og et Odelsthing”). Król, obejmując władzę, składał Stortingowi przysięgę, że będzie władać Królestwem Norwegii zgodnie $z$ jego konstytucją i prawami. Owo przyrzeczenie miało formę werbalną, jednak jeśli w czasie, w którym przysięga miała być złożona, Storting nie obradował, wówczas przyjmowało formę pisemną, która winna dojść do skutku przed obliczem Rady Państwa, a na kolejnym posiedzeniu parlamentu Król zobowiązany był ją uroczyście powtórzyć w formie ustnej. Przepis ten podkreśla, jak wielką rolę odgrywać miał organ przedstawicielski - Storting, który jako reprezentant Narodu przyjmował od Króla gwarancje rządów zgodnych $z$ ideą państwa prawa.

18 Tekst Konstytucji Królestwa Norwegii z 17 maja 1814 roku zaczerpnięty z pracy: P. Berg, F. Castberg, S. Steen, Arven fra Eidsvoll. Norges Grunnlov, Oslo 1945 s. 205-234. Tłumaczenie tekstu konstytucji dokonane przez autora.

${ }^{19}$ W czasie unii z Danią Norwegowie walczyli o zachowanie dziedziczności tronu norweskiego. 
Zgodnie z § 3 władza wykonawcza należała do Króla, który sprawował ją wspólnie $z$ mianowaną przez siebie Radą Państwa, niekiedy zwaną także Rządem. Stosunek władzy wykonawczej na linii Król - Rada Państwa trafnie ukazuje zdanie, które często spotyka się w norweskiej literaturze dotyczącej tego tematu „den utevønde makt var kongen i statsråd”. Zgodnie z § 28 Król osobiście wybierał Radę Państwa spośród obywateli norweskich, którzy ukończyli 30 rok życia. Monarcha rozdzielał także według własnego uznania obowiązki ciążące na poszczególnych członkach Rady. Organ ten miał się składać przynajmniej z pięciu członków, którzy odpowiadali za poszczególne dziedziny związane $z$ funkcjonowaniem państwa. W ten sposób wykreowano pięć stałych departamentów - ministerstw: finansów, prawa, wojny, oświaty i spraw zagranicznych. W razie potrzeby monarcha mógł powołać dodatkowych członków Rady Państwa ${ }^{20}$. W celu wyraźnego rozgraniczenia władzy ustawodawczej i wykonawczej prawodawca postanowił, że monarcha nie będzie mógł powoływać do Rady przedstawicieli zasiadających w Stortingu. Zabieg ten miał także zapobiec nadmiernemu skupianiu władzy przez jedną osobę lub grupę osób. Podobny charakter miała także regulacja zabraniająca zasiadania w tym samym czasie w Radzie Państwa ojcu i synowi lub dwóm braciom (§ 28 konstytucji). Zasiadanie w Radzie wiązało się z obligatoryjną obecnością jej członków na posiedzeniach. Konstytucja przewidywała wyjątek od tego stanu rzeczy, który związany był z nieobecnością usprawiedliwioną przez prawnie uzasadnione powody. W tym wypadku obowiązek przedstawiania spraw spoczywający na nieobecnym przekazywany był, zgodnie z § 31, na innego ministra wyznaczonego w tym celu przez Króla. Decyzje podjęte na posiedzeniu były ważne tylko w przypadku, kiedy na sali obecna była więcej niż połowa składu Rady Państwa. Wyjątek od tej zasady zachodził wówczas, gdy nieobecność wymaganej liczby ministrów usprawiedliwiona była przez prawnie uzasadnione powody - w tym wypadku Król miał prawo powołać innych wyższych urzędników do zajęcia miejsca w Radzie.

Konstytucja $z$ Eidsvoll nadała Królowi szereg uprawnień związanych $z$ władzą wykonawczą oraz ustawodawczą. Monarcha miano-

${ }^{20}$ Ibidem, s. 39. 
wał wyższych urzędników państwowych - cywilnych, wojskowych i kościelnych. Związane to było $z$ najwyższą funkcją, jaką pełnił w Kościele, wojsku oraz egzekutywie. Król - zanim mianował urzędników - był zobowiązany wysłuchać opinii Rady Państwa, co rzecz jasna nie miało ostatecznego wpływu na wybór personalny, opinia ta miała raczej charakter subsydiarny. Zgodnie z § 22 konstytucji, Król decydował także (po zapoznaniu się z opinią Rady Państwa) o zwolnieniach na stanowiskach wymienionych w ustawie. Przepis ten zawierał katalog zamknięty, przez co władza monarsza rozciągała się na: członków Rady, ambasadorów, konsulów, cywilnych i duchownych sędziów, przywódców regimentów i korpusów wojskowych, komendantów twierdz, wyższych dowódców okrętów wojennych oraz urzędników zatrudnionych przy przedstawicielstwach handlowych. W razie gdyby Król skorzystał $z$ tych uprawnień, zainteresowanym przysługiwała gwarancja uposażenia w wysokości ${ }^{2} / 3$ poprzednich poborów, którą pobierali do czasu aż Storting zdecydował o przyznaniu im emerytury (pension) - dożywotniego uposażenia $z$ racji pełnionego stanowiska państwowego. Wielu urzędników nie mogło być zwolnionych bez wyroku sądowego, w tym wypadku monarcha mógł jedynie zawiesić ich działalność.

Król posiadał także najwyższą władzę w Kościele państwowym, jego zgody wymagały wszelkie decyzje na polu religijnym. W sprawach tych monarcha mógł posiłkować się opinią superintendentów (odpowiednicy katolickich biskupów), ale nie był do tego zobowiązany. Władza owa przejawiała się w możliwości wydawania dyrektyw dla całego Kościoła oraz wszystkich posiedzeń i zebrań o charakterze religijnym. Król miał czuwać także nad odpowiednią interpretacją zasad wiary przez nauczycieli religijnych. Zgodnie z konstytucją religia ewangelicko-augsburska była oficjalną religią państwową, a mieszkańcy ją wyznający byli zobowiązani do wychowania w niej swoich dzieci.

Ustawa zasadnicza Królestwa Norwegii dawała Królowi możliwość skorzystania z prawa łaski. Monarcha mógł ułaskawić przestępców po wydaniu wyroku przez Sąd Najwyższy. W razie spraw, które Odelsting (część Stortingu) wnosił w celu rozpatrzenia do Trybunału Królestwa (w skład Trybunału wchodzili członkowie Lagtingu i Sądu Najwyższego, o czym dalej), Król miał jedynie możliwość 
zastosowania prawa łaski od zasądzonej kary śmierci. Owo ograniczenie wynikało $z$ racji tego, że Trybunał był organem o charakterze politycznym, w którym Storting miał stanowczą władzę, królewskie prawo łaski ingerowało więc jedynie częściowo w kompetencje parlamentu.

Pomimo, iż konstytucja pozbawiła Króla możliwości nadawania tytułów szlacheckich oraz przywilejów, mógł on wedle własnego uznania nadawać ordery i odznaczenia, co musiał czynić w sposób oficjalny i wyłącznie za wybitne zasługi. Uhonorowanie danej osoby nie łączyło się, jak już wcześniej wspomniałem, z dostępem do wyższych urzędów państwowych ani nie zwalniało od spełniania obowiązków obywatelskich. Wszelkie rangi i tytuły były odtąd ściśle powiązane $z$ danym urzędem, a zachować je mógł jedynie urzędnik zwolniony w sposób „honorowy” (§ 23 konstytucji).

Król był także zwierzchnikiem sił zbrojnych, miał prawo zarządzać mobilizację, zacząć wojnę, podpisać pokój, zawrzeć czy zerwać sojusz. Władza monarsza dotycząca kwestii wojskowych została ograniczona przez zakaz przekazywania jej obcym państwom, co miało zapobiec wyprowadzaniu wojsk poza granice kraju. Konstytucja, stojąc na straży suwerenności i niepodległości kraju, zabraniała także wkraczania obcych wojsk na teren państwa, chyba że byłyby to siły pomocnicze skierowane do walki $z$ agresorem - decyzja o niezastosowaniu tego przepisu leżeć miała w gestii Stortingu.

W wyjątkowych okolicznościach monarcha miał także wpływ na wybór swojego następcy. $Z$ racji tego, że Norwegia była monarchią dziedziczną, był to wypadek wyjątkowy - w razie braku Księcia uprawnionego do sukcesji, Król mógł zasugerować Stortingowi swojego sukcesora. Ostateczna decyzja należeć miała jednak do Stortingu.

Wszelkie decyzje ( $z$ wyjątkiem spraw dyplomatycznych i wojskowych) związane $z$ egzekutywą podejmowane były w Radzie Państwa. Ostateczny głos należał do monarchy, dla którego, zgodnie z § 32, Rada Państwa miała być jedynie organem doradczym. Każdy członek Rady miał prawo wypowiedzieć otwarcie swoje zdanie, a Król był zobowiązany do wysłuchania opinii, przy czym - jak wcześniej wspomniałem, decyzja zastrzeżona była dla monarchy. Konstytucja zakładała jednak możliwość, w której członkowie Rady mogli nie 
zgodzić się z opinią Króla. Przesłanki, które musiały być spełnione, aby ów protest można było uznać $\mathrm{z}$ zgodny $\mathrm{z}$ ustawą, to: niezgodność opinii z prawem krajowym, formą państwa lub podjęcie decyzji szkodliwej dla państwa - dla zaistnienia tego stanu rzeczy wystarczyło spełnienie jednej z nich. Wówczas złożenie wyraźnego protestu było obowiązkiem członka Rady, a utrwalenie protestu miało formę zapisu w protokole prowadzonym przez Radę Państwa. Brak wyraźnego protestu równał się $z$ aprobatą królewskiej decyzji, a $z$ racji tego, że Król zgodnie $z$ prawem nie ponosił odpowiedzialności (pomimo że wszystkie rządowe decyzje i polecenia wydawane były zawsze w imieniu Króla), ta spadała na członków Rady.

Paragraf 35 wprowadził do norweskiej konstytucji instytucję kontrasygnaty. Kontrasygnata polegała na dodatkowym podpisaniu aktu prawnego przez wyznaczoną do tego osobę, dzięki czemu odpowiedzialność polityczna spadała na podpisującego, a dokument nabierał mocy obowiązującej. Kontrasygnata wykluczała odpowiedzialność Króla za błędne decyzje i przenosiła ją na odpowiedniego ministra. Zgodnie z § 2 konstytucji „Osoba Króla jest święta: Króla nie można ganić albo oskarżać. Odpowiedzialność spoczywa na jego Radzie". Norweska ustawa zasadnicza wymagała kontrasygnaty decyzji królewskich oraz oficjalnych listów. Minister odpowiedzialny za przedmiot regulacji oprócz podpisania dokumentu winien był wprowadzić rezolucję królewską do protokołu.

W pewnych określonych w konstytucji wypadkach Rada Państwa sprawowała także władzę regencką w państwie. Po pierwsze, sytuacja ta miała miejsce, kiedy w chwili śmierci Króla dziedzic tronu był niepełnoletni. Wówczas Rada sprawowała władzę wraz z Królową wdową, która była matką następcy tronu, lub z najbliższym uprawnionym do dziedziczenia księciem, który ukończył 25 lat (na wypadek śmierci Królowej matki). Po drugie, jeśli nie ma ani Królowej matki, ani dalszego następcy tronu, Rada miała sprawować władzę wraz z wskazanymi przez Storting osobami. Po trzecie, sytuacja taka mogła nastąpić w razie choroby umysłowej Króla, niezdolności do władzy lub nieobecności w królestwie. Rada była także obowiązana do zwołania nadzwyczajnego Stortingu w chwili śmierci Króla. 


\subsection{Władza ustawodawcza}

Zgodnie z § 49 konstytucji władza ustawodawcza należała do Narodu, a jej wykonawcą był parlament zwany Stortingiem, który składał się z dwóch części: Lagtingu i Odelstingu. W powyższej regulacji kryją się dwie ważne zasady ustroju Norwegii - zasada zwierzchnictwa Narodu oraz reprezentacji politycznej. Władza miała więc pochodzić od Narodu oraz być przez niego wykonywana, a jego reprezentację stanowili wybierani w wyborach pośrednich przedstawiciele zasiadający w parlamencie. Reguła ta znalazła się wśród 11 głównych postanowień sporządzonych przez Komisję Konstytucyjną - jej celem było opracowanie zasad, na których będzie opierać się norweska ustawa zasadnicza - „folket bør udøve den lovgivende Magt gjennem sine Repræsentantere" ${ }^{21}$. Konstytucja powołała do życia jednoizbowy parlament - Storting, który składał się z dwóch części - Lagtingu oraz Odelstingu. Pomimo podziału Stortingu na dwie części był to organ jednoizbowy, co przyjmuje się także w norweskiej doktrynie prawa konstytucyjnego. Za powyższym twierdzeniem przemawia szereg argumentów, z których do najważniejszych możemy zaliczyć: Storting utworzony został w drodze jednych wyborów, funkcjonował jako jeden organ, nie istniały żadne specjalne warunki dla członkostwa w jednej z części, obie części działały w tej samej kadencji, komisje parlamentarne tworzone były z przedstawicieli obu części, posiedzenia plenarne odbywały się razem $^{22}$. Zgodnie $z \S 59$ liczba deputowanych nie mogła być mniejsza niż 75 i nie większa niż 100, z czego większość posłów miała być pochodzenia chłopskiego (,Reprezentanci miast będą w stosunku do reprezentantów wsi jak jeden do dwóch, a liczba reprezentantów w całości nie powinna być mniejsza niż 75 i większa niż 100”).

Zwyczajny Storting zwoływany był raz na trzy lata, a otwarcie sesji następowało pierwszego powszedniego dnia lutego. Obrady

${ }^{21}$ K. Mykland, T. Opsahl, G. Hansen, Norges grunnlov i 175 år, Oslo 1989, s. 47.

${ }^{22}$ Konstytucja Królestwa Norwegii, wstęp i tłum. A. Majtan i S. Sagan, Wrocław 1989, s. 18-19. 
miały trwać nie dłużej niż trzy miesiące, chyba że zgodę na ich przedłużenie wyraziłby Król. Zwyczajna sesja parlamentu otwierana i zamykana była przez Króla. Po ukonstytuowaniu się Stortingu monarcha lub wyznaczona przez niego osoba otwierała obrady specjalną mową, w której poruszano tematy związane ze stanem Królestwa Norwegii. Wedle ustawy członkowie parlamentu wybierali spośród siebie jedną czwartą deputowanych, którzy tworzyli Lagting - który miał charakter sądowniczy i prawodawczy, pozostała część tworzyła Odelsting. Oba filary Stortingu miały odrębnego sekretarza oraz prezydenta, a obrady odbywały się oddzielnie. Żadna z części Stortingu nie mogła zebrać się, jeżeli nie były obecne $2 / 3$ ich członków. Kadencja deputowanych, zarówno zwyczajnego, jak i nadzwyczajnego Stortingu, trwała trzy lata.

Nadzwyczajny Storting mógł być zwołany tylko i wyłącznie przez Króla, zgodnie $z$ jego dobrą wolą - dawało to Królowi uprawnienia w dziedzinie władzy ustawodawczej oraz przewagę nad Stortingiem. Paragraf 17 konstytucji nadawał monarsze kompetencje ustawodawcze w dziedzinie handlu, ceł, gospodarki oraz służb porządkowych (policji). Król mógł w powyższej materii wydawać oraz uchylać rozporządzenia. Królewskie rozporządzenia - ordonanse - miały charakter prowizoryczny (tymczasowy) i obowiązywały między posiedzeniami parlamentu (tzn. ich moc wygasała wraz $\mathrm{z}$ rozpoczęciem kolejnego posiedzenia). Ponadto musiały być one zgodne $z$ ustawą zasadniczą Królestwa Norwegii oraz ustawami Stortingu. W rzeczywistości konstytucja gwarantowała przewagę egzekutywy nad legislatywą, gdyż zwyczajne zebrania parlamentu odbywały się co trzy lata (bez zgody Króla mogły trwać maksymalnie trzy miesiące), a sesje nadzwyczajne zależały od osobistej decyzji Króla. Tym samym ordonanse królewskie mogły obowiązywać latami i wywierać wpływ na politykę państwa. Król miał także prawo, w nadzwyczajnych okolicznościach, wydawać zarządzenia sprzeczne $\mathrm{z}$ regułami konstytucji i ustawodawstwem Stortingu ${ }^{23}$.

Do najważniejszych uprawnień Stortingu należało wedle konstytucji stanowienie praw oraz podatków ${ }^{24}$. Jak wynika z $§ 19$ podatki

${ }^{23}$ Grunnloven med forklaringer, s. 15.

${ }^{24}$ Ibidem, s. 34. 
nałożone przez Storting egzekwował Król. Podatek taki obowiązywał do dnia pierwszego lipca tego roku, w którym zbierał się nowy zwyczajny Storting - podatki, opłaty, cła i inne należności publiczne ustalone przez Storting mogły być pobierane przez całą jego kadencję. Nowy parlament miał prawo zrezygnować $z$ ich egzekwowania i ustalić nowe podatki, mógł także podtrzymać je przez wyraźne przywrócenie. Parlament posiadał także rozległe kompetencje finansowe i kontrolne. Storting podejmował decyzje dotyczące rozpisania pożyczek państwowych, nadzorował sprawy finansowe Królestwa (zajmowali się tym mianowani przez parlament rewizorzy), ustalał sumy pieniężne przeznaczone na wydatki państwowe, decydował o wysokości kwot przeznaczonych na utrzymanie dworu oraz określał apanaże rodziny królewskiej. Storting kontrolował działalność Rady Państwa oraz administracji państwowej, $z$ wyjątkiem spraw wojskowych. Miał wgląd do wszystkich protokołów rządowych, publicznych dokumentów i raportów. W związku z prymatem Króla w materii polityki zagranicznej, Storting miał jedynie prawo żądania informacji o traktatach i umowach królewskich $z$ innymi państwami, z zastrzeżeniem umów opatrzonych klauzulą tajności ${ }^{25}$. Każdy, z wyjątkiem Króla i jego rodziny (chyba że któryś z książąt pełni urząd państwowy), mógł być wezwany przed oblicze parlamentu w sprawach związanych $z$ dobrem państwa. Do kompetencji Stortingu należało także mianowanie urzędników państwowych zwanych rewizorami, którzy co roku sprawdzali rachunki państwowe, a po dokonaniu kontroli publikowali odpowiednie wyciągi informujące o stanie finansowym państwa. Parlament odpowiadał także za naturalizowanie obcokrajowców.

Storting posiadał także uprawnienia prawodawcze. Aby wszelkie decyzje i inicjatywy mogły być uważane za wiążące, wymagana była obecność co najmniej $2 / 3$ członków danego Tingu (Odelsting, Lagting). Inicjatywa ustawodawcza przysługiwała członkom Rządu (Rada Państwa) oraz Odelstingu - tylko oni mogli wnieść projekt ustawy pod głosowanie. Propozycje ustaw można było zgłosić na forum Odelstingu, który albo odrzucał projekt, albo go przyjmował. Przyjęty projekt trafiał następnie do Lagtingu, który mógł go

${ }^{25}$ P. Berg, F. Castberg, S. Steen, op.cit., s. 45. 
zatwierdzić lub odrzucić. W tym drugim wypadku Lagting przesyłał projekt ustawy do Odelstingu, dołączając do niego poczynione przez jego członków uwagi. Uwagi te były następnie rozpatrywane przez Odelsting, który mógł odłożyć projekt ustawy lub też przesłać go $z$ powrotem do Lagtingu ze zmianami albo bez nich. Projekt dwukrotnie odrzucony przez Lagting trafiał pod głosowanie Stortingu, który mógł przyjąć bądź odrzucić projekt ustawy kwalifikowaną większością dwóch trzecich głosów w obecności ustawowej liczby posłów $^{26}$. Procedura taka miała chronić deputowanych $z$ ośrodków miejskich, którzy znajdowali się w zdecydowanej mniejszości w stosunku do deputowanych warstwy bønder, przed powstawaniem bondelov. Deputowani chłopscy musieli liczyć się ze zdaniem społeczności miejskiej, której reprezentanci mogli dzięki uczestnictwu w organach Stortingu (głównie Lagtingu) blokować niekorzystne dla nich projekty ustaw ${ }^{27}$.

Przyjęty przez Lagting bądź Storting projekt ustawy wymagał sankcji królewskiej, dla uzyskania której delegacja obu części Stortingu udawała się do monarchy. Król po zaaprobowaniu projektu składał pod nim swój podpis, co powodowało, że stawał się on obowiązującą ustawą. Monarcha miał także możliwość weta odraczającego, które nie miało jednak niewzruszalnego charakteru. Jeśli monarcha nie aprobował projektu ustawy, wysyłał go z powrotem do Odelstingu $z$ oświadczeniem, że nie uważa za stosowne w danym momencie nadać projektowi sankcji. Ustawa zawetowana przez Króla mogła być ponownie przedstawiona przez Storting dopiero na następnym zwyczajnym zebraniu (za trzy lata), oczywiście po przejściu procedury ustawodawczej. Także wówczas Królowi przysługiwało weto, które dopiero za trzecim razem (obrady trzeciego Stortingu) nie powodowało odrzucenia projektu, który stawał się ustawą. Warunkiem była jedynie niezmieniona treść projektu oraz ponowne przyjęcie projektu przez obie izby parlamentu. W praktyce zastosowanie instytucji weta mogło powodować odroczenie niewygodnego dla Króla projektu ustawy nawet na sześć lat (po siedmiu latach zbierał się trzeci Storting, który mógł bez sankcji królew-

26 S. Steen, Det frie Norge 1814, Oslo 1951, s. 173.

27 P. Berg, F. Castberg, S. Steen, op.cit., s. 45. 
skiej przyjąć dany projekt). Regulacja ta $\mathrm{w}$ powiązaniu $\mathrm{z}$ innymi przepisami konstytucji (sesja zwyczajna raz na trzy lata, decyzja o możliwości zwołania nadzwyczajnego Stortingu w rękach Króla, prawo Króla do wydawania i anulowania aktów prawodawczych etc.) tworzyła sytuację, w której władza wykonawcza przeważała nad władzą ustawodawczą - konstytucja zakładała silną pozycję monarchy, który był nie tylko reprezentantem norweskiego społeczeństwa, ale także prawodawcą i beneficjentem władzy wykonawczej. Zgodnie z § 80 sesja Stortingu nie mogła trwać dłużej niż trzy miesiące, chyba że Król zadecydował inaczej. Wszystkie ustawy zaakceptowane przez monarchę opatrzone były jego podpisem i pieczęcią Królestwa, a także wydawane były w jego imieniu.

Istniała grupa projektów ustaw, która nie wymagała sankcji królewskiej. Przepisy $\S 83$ wymieniały taksatywnie wymienione projekty. Do tego specjalnego zbioru należały przepisy decydujące o sprawach związanych $z$ policją; projekty odrzucone lub przyjęte przez wszystkich obecnych deputowanych; akty normatywne, na mocy których Storting naturalizował cudzoziemców; projekty, w których Odelsting nakładał na członków Rady Państwa albo na innych akt oskarżenia; akty, które potwierdzały albo odrzucały decyzje o sporach wyborczych. Storting mógł w każdym momencie zasięgnąć rady Sądu Najwyższego we wszelkich sprawach związanych ze stanowieniem i interpretacją prawa.

Storting debatował przy otwartych drzwiach, co oznaczało, że obrady parlamentarne były jawne. Ze względów technicznych (na wypadek zbyt dużej liczby zainteresowanych tokiem obrad) przebieg obrad Stortingu był ogłaszany drukiem, co umożliwiało dostęp do nowo stanowionych treści prawnych dla ludności i zapewniało ze strony technicznej jawność obrad. Wyjątek od tej zasady stanowiły informacje tajne, które zastrzeżone zostały przez parlamentarzystów podczas prac legislacyjnych. Po zakończeniu prac albo po upływie wyznaczonego przez konstytucję czasu, Król zamykał sesję, zawiadamiając jednocześnie o swoim stanowisku wobec projektów ustaw, o których ważności jeszcze nie zadecydował. Wszystkie projekty, których Król nie zaakceptował w sposób wyraźny, uważane były za odrzucone. 
Storting posiadał także pewne kompetencje związane $\mathrm{z}$ osobą Króla. Przede wszystkim decydował (wspólnie $z$ Królową wdową) o edukacji niepełnoletniego monarchy, w wypadku gdy jego ojciec nie pozostawił żadnych pisemnych wskazówek. Co ważniejsze jednak, w wyjątkowych sytuacjach wybierał następcę tronu. Tego typu uprawnienia przysługiwały Stortingowi w wypadku, gdy wygasła męska linia królewska i nie został wyznaczony żaden następca tronu. Parlament (sesja nadzwyczajna) zbierał się także w chwili śmierci Króla oraz dla ustalenia władzy regenckiej.

\subsection{Władza sądownicza}

Konstytucja Królestwa Norwegii uregulowała także częściowo kwestie związane $z$ sądownictwem. Ustawa zasadnicza powołała do życia Trybunał Królestwa oraz Sąd Najwyższy. Trybunał był sądem o charakterze politycznym, który tworzyli sędziowie Sądu Najwyższego oraz członkowie Lagtingu, przewodniczącym był Prezydent Lagtingu. O postawieniu przed Trybunałem Królestwa decydowali członkowie Odelstingu, którzy wnioskowali o postawienie w stan oskarżenia tych członków Rady Państwa, Sądu Najwyższego lub Stortingu, którzy dopuścili się przestępstw w związku z pełnionym przez siebie stanowiskiem. Czyny takie musiały być niezgodne z konstytucją lub ustawami państwowymi. Utworzenie tego typu organu było potrzebne $z$ racji tego, że sądownictwo monarsze ograniczało się jedynie do rodziny królewskiej i nie obejmowało członków administracji publicznej. Król posiadał jedynie prawo łaski, które chroniło skazanego przez Trybunał tylko i wyłącznie od orzeczonej kary śmierci ${ }^{28}$. Oskarżony mógł na własne życzenie usunąć do 15 członków składu orzekającego, chyba że ten składał się z mniej niż 15 sędziów.

W czasie prac dotyczących kwestii sądownictwa dochodziło do wielu sporów, z których najbardziej zagorzały dotyczył kwestii Trybunału. Część członków Zgromadzenia Narodowego opowiadała się

28 S. Dyrvik, Året 1814, Oslo 2005, s. 87. 
za tym, aby organ ten nie miał stricte politycznego charakteru. Reprezentantem owej grupy był sorenskriver (urząd utworzony w 1591 roku - początkowo pisarz sądowy, a następnie sędzia okręgów wiejskich) Christie, który w swojej wypowiedzi z 11 maja 1814 roku zaznaczył, że przewodniczącym Trybunału powinien być sędzia przewodniczący Sądu Najwyższego, który z racji swojej wiedzy i wykształcenia prawniczego nadawałby się do tego bardziej niż Prezydent Lagtingu ${ }^{29}$. W wypowiedzi deputowanego $z$ Bergen kryła się chęć uczynienia $z$ Trybunału Stanu organu fachowego i pozbawionego nadmiernego upolitycznienia, na czele którego stać miałby zawodowy sędzia. Zabieg taki miałby służyć zapobiegnięciu ewentualnym sytuacjom, w których Trybunał stałby się areną walk politycznych. W podobnym tonie wypowiadał się Georg Sverdrup, proponujący, aby liczba członków Lagtingu w Trybunale nie była większa niż sędziów Sądu Najwyższego ${ }^{30}$. Ostatecznie Zgromadzenie nie przyjęło powyższych propozycji i przepisy konstytucji nie uregulowały liczby sędziów Trybunału pochodzących $z$ Lagtingu oraz z Sądu Najwyższego.

Konstytucja powołała do życia sąd ostatniej instancji, którym był Sąd Najwyższy, składający się z co najmniej sześciu sędziów oraz sędziego przewodniczącego (sędziowie powoływani byli przez Króla). Sędziowie nie mogli mieć mniej niż 30 lat, musieli oni cieszyć się autorytetem oraz posiadać wysoki poziom wiedzy prawniczej oraz duże doświadczenie. Podobnie jak w przypadku Trybunału Królestwa od orzeczenia Sądu Najwyższego nie przysługiwało odwołanie (decyzja nieweryfikowalna), skazany mógł ubiegać się jedynie o łaskę królewską - był to więc sąd ostatniej instancji ${ }^{31}$. W czasach pokoju Sąd Najwyższy pełnił także funkcję sądu drugiej instancji w sprawach wojskowych (wówczas w skład składu orzekającego wchodziło dodatkowo dwóch wysokich rangą oficerów powołanych przez Króla).

\footnotetext{
${ }^{29}$ E. Fure, Eidsvoll 1814: hvordan grunnloven ble til, Oslo 1989, s. 214.

${ }^{30}$ Ibidem, s. 215.

${ }^{31}$ S. Dyrvik, op.cit., s. 87.
} 


\section{Wnioski końcowe}

Konstytucja Królestwa Norwegii obowiązuje ze zmianami po dzień dzisiejszy. W XIX- i XX-wiecznej historii kraju odegrała ona znaczącą rolę. Przede wszystkim po zawarciu unii norwesko-szwedzkiej obowiązywała na równi z konstytucją szwedzką (do ustawy wprowadzono jedynie zmiany, które były konieczne ze względu na zawarcie unii), dzięki czemu sytuacja $z$ czasów monarchii Oldenburgów nie powtórzyła się ${ }^{32}$. Samo zawarcie unii było sukcesem Zgromadzenia Narodowego oraz króla Chrystiana Fryderyka, gdyż w walce zbrojnej norweskie siły zbrojne były bez szans, a państwa zachodnie opowiedziały się po stronie Szwecji, której terytorium Norwegii należało się zgodnie $z$ postanowieniami z Kolonii (o czym mowa była w pierwszej części pracy). Podobnie wielką rolę konstytucja odegrała w 1905 roku, kiedy doszło do zerwania unii ${ }^{33}$. Norwegowie powołali się na zapis mówiący o tym, że oba kraje łączy jedynie osoba Króla, a ten

32 Prace nad zmianą konstytucji rozpoczęły się 26 października, a zakończyły 4 listopada. Główne postanowienia dotyczyły unii ze Szwecją - odtąd oba państwa łączyła osoba monarchy. Każdy następny król koronowany był oddzielnie jako władca Norwegii i Szwecji. Norweski rząd został podzielony na dwie części: kiedy król przebywał w Sztokholmie, wraz z nim w Szwecji musiał urzędować norweski premier wraz z dwoma innymi członkami rządu (w drugą stronę działało to analogicznie). W tym czasie w Christianii, w celu utrzymania ciągłości rządów, tworzono tzw. kolegium rządowe składające się z co najmniej pięciu ministrów. Król posiadał także prawo mianowania wicekróla lub stattholdera na czas, kiedy był nieobecny w Norwegii. Ministerstwo spraw zagranicznych było wspólne dla obu państw i miało swoją siedzibę w Sztokholmie, w rzeczywistości chodziło o to, aby odizolować Norwegię od polityki międzynarodowej i przekazać wszelkie kompetencje w tym temacie stronie szwedzkiej. Przepisy konstytucji z 4 listopada gwarantowały Norwegom własny bank, monetę, flagę oraz wojsko. Osobne były także parlamenty, a wspólne obrady rządów obu państw odbywały się w Christianii bądź Sztokholmie. Jeśli spotkanie miało miejsce w Szwecji, wówczas przy królu musiało zasiadać trzech członków rządu norweskiego, jeżeli było na odwrót to samo dotyczyło polityków szwedzkich. Aby nie zaniedbywać swoich obowiązków i nie faworyzować żadnej z części nowego państwa, monarcha winien był przebywać przez pewien czas w Norwegii. Trzon konstytucji pozostał jednak bez zmian.

${ }^{33}$ Zob. A. Bereza-Jarociński, op.cit., s. 223 i n. 
pełni swoją władzę za pośrednictwem rządu. Kiedy Król odmówił powołania rządu, przestał tym samym wykonywać swoje obowiązki względem Norwegii, a więc przestał pełnić funkcję monarchy.

Odnosząc się do zasady trójpodziału władzy w konstytucji eidsvollskiej, należy zaznaczyć, że miała ona na celu nie tylko funkcjonalno-organizacyjny podział władzy, ale także wzajemne hamowanie się władz, tak aby żadna $z$ nich nie skupiła w swoich rękach zbyt dużych kompetencji. W rzeczywistości znacznie więcej uprawnień przysługiwało Królowi, który wraz z Radą sprawował władzę wykonawczą, przez wydawanie ordonansów władzę ustawodawczą, a także miał wpływ na władzę sądowniczą za sprawą mianowania sędziów. Tak silna pozycja Króla wynikała $z$ tradycji oraz szacunku, jakim społeczeństwo norweskie darzyło osobę monarchy. Podsumowując, można stwierdzić, że pomimo wprowadzenia trójpodziału władzy, przepisy konstytucji gwarantowały przewagę egzekutywy nad legislatywą oraz silną pozycję Króla, którego władza ograniczona była przez parlament zwany Stortingiem.

\section{STRESZCZENIE}

Relacje między organami władzy ustawodawczej, wykonawczej i sądowniczej w świetle Konstytucji Królestwa Norwegii $\mathrm{z}$ dnia 17 maja 1814 roku

Autor artykułu przybliża czytelnikowi relacje pomiędzy organami władzy ustawodawczej, wykonawczej i sądowniczej w świetle Konstytucji Królestwa Norwegii z dnia 17 maja 1814 roku. Analiza konstytucyjnych uprawnień i obowiązków Króla, Rady Państwa, parlamentu oraz sądów poprzedzona jest wstępem o charakterze historycznym, który ma na celu przybliżenie dziejów Norwegii, patrząc przez pryzmat rozwoju prawa w tym kraju. Relacje pomiędzy organami państwa zostały przedstawione w oparciu o monteskiuszowski trójpodział władzy $z$ uwzględnieniem jej trzech podstawowych zasadach: społecznego podziału władzy, funkcjonalno-organizacyjnego podziału władzy, a także zasady checks and ballances. Autor przybliżył także nowatorskie rozwiązania, które XIX-wieczny ustawodawca norweski zawarł w konstytucji roku 1814, takie jak np. możliwość głosowania korespondencyjnego. Temat opracowany został $z$ uwzględnieniem tła historycznego i kulturowego XVIII i XIX-wiecznej Norwegii. 
Słowa kluczowe: konstytucja eidsvollska, Norwegia, trójpodział władzy, władza ustawodawcza, władza wykonawcza, władza sądownicza.

\section{SUMMARY}

Relations between the legislature, executive and judiciary with reference to Constitution of the Kingdom of Norway of 17 May 1814

The article introduces the relationship between the bodies of legislative, executive and judiciary with reference to the Constitution of The Kingdom of Norway set on 17 May 1814. Historical introduction presents history of Norway, focusing on the development of law in this country. Main part starts with analyse of the constitutional powers and duties of the King, the Council of State, Parliament and the courts. Relations between the countries were presented based on Montesquieu's separation of powers with regard to the three basic principles: the social division of power, functional and organizational separation of powers and the principle of checks and ballances. As well, author discussed the innovative solutions that nineteenth century Norwegian legislator has included in the Constitution of 1814, such as the possibility to vote by correspondence. Subject has been studied taking into account the historical and cultural background of the Norway eighteenth and nineteenth century.

Keywords: eidsvol costitution, norway, tripartite system, legislative, executive, judiciary.

\section{BIBLIOGRAFIA}

Aschehoug T.H., Norges offentlige ret, bd. 1: Statsforfatningen i Norge og Danmark indtil 1814, Christiania 1866.

Bereza-Jarociński A., Zarys dziejów Norwegii, Warszawa 1991.

Berg P., Castberg F., Steen S., Arven fra Eidsvoll. Norges Grunnlov, Oslo 1945.

Dyrvik S., Året 1814, Oslo 2005.

Fure E., Eidsvoll 1814: hvordan grunnloven ble til, Oslo 1989.

Gaca A., Kodeks duński króla Chrystiana V z roku 1683, Torun 1992.

Grunnloven med forklaringer, red. H. Hartmann, Oslo 1959. 
Gunnes E., Norges historie bd. 2: Rikssamling og kristning 800-1177, red. K. Mykland, Oslo 1976.

Jørgensen P.J., Dansk retshistorie, København 1969.

Klementowski M., Powszechna historia ustroju, Warszawa 2012.

Konstytucja Królestwa Norwegii, wstęp i tłum. A. Majtan i S. Sagan, Wrocław 1989.

Larsen K., A history of Norway, New York 1950.

Mykland K., Opsahl T., Hansen G., Norges grunnlov i 175 år, Oslo 1989. Nordstrom B.J., Scandinavia since 1500, Minneapolis 2000.

Norges gamle lov, række 2: 1388-1604, bd. 2: 1448-1482, red. O.A. Johnsen, O. Kolsrud, A. Taranger, Oslo 1934.

Norsk tro og tanke, red. J.E. Ebbestad Hansen, bd. 1, Oslo 1998.

Sogner S., Aschehougs Norges historie bd. 6: Krieg og fred 1660-1780, red. K. Helle, Oslo 2005.

Steen S., Det frie Norge 1814, Oslo 1951. 
